forests form an almost continuous belt of varying width running parallel to the coast. They are said to hold great timber wealth of large dimensions. They have not been exploited, however, to anything like the extent of the rain forests owing to their geographical position, which places them outside the zone of streams and rivers suitable for floating timber.

The object of Mr. MacGregor's memoir is to record all the experimental and research work in connexion with the sylviculture of the mixed deciduous forest type upon which he has been specially engaged; or on which other officers have obtained some experience of, for example, plantation work. In the latter work, fuel plantations have formed an important branch. Large areas of indigenous species have been planted at Akilla, Ondo Circle. At Mamu and Olokemeji teak has been successfully grown-but almost, until recently, at the expense of good local indigenous species. Latterly, however, research work in the nursery and plantation has been devoted to the study of the requirements of indigenous species with the view of replacing exotic species when possible.

It is a curious anomaly that here in the West African tropical forests, with a plethora of magnificent timber trees of which almost the only one known, during the past century at least, was mahogany, the first commencements of forest plantation work on a scientific basis should have been made with teak in several colonies to the neglect of some of the, admittedly little-known, indigenous species. The research work with the latter undertaken by $\mathrm{Mr}$. MacGregor and ably depicted in this memoir proves that West Africa has timbers which will probably, in the future, be able to hold their own on any timber market in the world.

In addition to the nursery and experimental plantation work undertaken with indigenous species, sylvicultural experimental work in connexion with both artificial and natural regeneration has been commenced with considerable success.

Chapters are devoted to the description of the sylvicultural characters of a number of species, indigenous and exotic, and some excellent deseriptions of seedlings. Finally, there is a report on the soils at Olokemeji by Mr. H. C. Doyne, senior agricultural chemist, and Mr. W. A. Watson, agricultural chemist, Ibadan.

Although perhaps it is too early to accept the mass of detail recorded in this important memoir as actually proved, without further check, yet Nigeria may be complimented on the methods upon which the work has been carried out.

\section{The Broadcasting Wave-Lengths of Europe}

$7 \mathrm{HE}$ plan for allocating the wave-lengths of the broadcasting stations in Europe published in 1934, and known as the Lucerne plan, is getting more and more difficult to work. The trouble arises mainly from the fact that the full range of frequencies available for the carrier waves is 1,350 kilocycles per second, and in order to prevent serious overlapping, each station requires a width of about 10 kilocycles per sec. In order to secure agreement between the various nations concerned, it was necessary to allocate 133 channels to 170 working stations, so that some had to work at the same frequency, care being taken to give these frequencies to small stations at a great distance from one another.

Unfortunately, little attention had been given to limiting the power of large broadcasting stations, and so there are now thirteen in Europe which work at 100 kilowatts or above, eighteen with powers not less than $50 \mathrm{kw}$. and twenty with powers not less than $20 \mathrm{kw}$. Many of these stations are transmitting through the same zone of darkness, and it follows that the spectra of the waves radiated by powerful stations in contiguous channels will overlap. The overlapping sidebands of these unwanted stations produce serious interference.

In a paper on broadcast transmission read to the Institution of Electrical Engineers on May 1 by $\mathrm{Mr}$. P. P. Eckersley, it is pointed out that at the present time the designer of a receiver capable of reproducing distant as well as local programmes is forced to cut off the upper audio frequencies of modulation, and this deleteriously affects the quality of the reproduction. The ordinary commercial receiver sold to-day to the public cuts off the audio frequencies above 3,500 cycles per second.

The only way to get over this difficulty is to change radio technique. It is improbable that European nations will agree to limit either the existing power or the number of their working stations. But if it were possible to modify transmitters so that the spectra of the waves radiated contained the carrier wave and only one set of sidebands, spectrum overlap could be minimised and in some cases entirely eliminated. If a frequency band of 2,000 cycles per second could be added to the ordinary breadth, a great improvement would result. The introduction of high-fidelity broadcasting would undoubtedly stimulate the industry of radio broadcasting.

Mr. Eckersley has recently been to the United States and has inspected the apparatus developed by Wired Radio Inc. for use in connexion with their high-frequency broadcasting system. He found that several of the methods he recommended were similar to their methods, and that a very high quality of reproduction was achieved.

\section{University and Educational Intelligence}

CAMBRIDGE.-The sixth course of Scott Lectures will be given by Prof. G. Hevesy in the Cavendish Laboratory at 4.30 p.m. on May 13,15 and 17 . The subject of the course will be "The Terrestrial and Cosmic Abundance of the Elements".

An election to the Isaac Newton Studentship will be held in the Michaelmas Term 1935. These studentships are for the furtherance of advanced study and research in astronomy and physical optics and are open to those members of the University who have obtained a degree in the University and were less than twenty-five years of age on January 1, 1935. Candidates are invited to send in their applications to the Vice-Chancellor between October 8 and 14 , 1935. The emolument of the student will be $£ 250$ per annum.

Edinburgh.-Mrs. Stewart Hall has given $£ 15,000$ for the endowment of a lectureship in the pathology of the diseases of children.

On the recommendation of the Joint Committee of the University Court and the managers of the Royal Infirmary, Dr. A. E. Barclay, lecturer in medical radiology, University of Cambridge, has been appointed lecturer in radiology in the University, on his appointment as radiologist to the Royal Infirmary from May 1, 1935. 
THE International Federation of University Women held a meeting at Budapest in September last, when twenty-six national federations were represented. Among the resolutions adopted was one deprecating the "tendency, increasingly evident in the majority of countries, by new regulations to debar women from careers for which they are well qualified, whether on grounds of sex or marriage" and declaring such regulations to be "inimical to the family which is itself the foundation of society". Another deplores the contravention in certain countries of the principles that teaching history, etc., in schools should be impartial and that art, literature and science are a common human heritage and not the appanage of particular nations or races. The German Federation has passed through a difficult period, and it is hoped to reconstruct it on a basis which will eliminate discrimination on any racial, political or religious grounds. The Austrian Federation was concerned about the bad effect of recent legislation on the position of women. The Indian Federation reported a surprisingly large number of members-400. The British Federation gave scholarships last year enabling three German scholars and scientific workers who had lost their positions on account of their nonAryan nationality or political opinions to live at Crosby Hall, London. The next conference of the International Federation is to be held in 1936 in Poland.

"FrEEDOM or Indoctrination: an Enduring Dilemma of Education" : a paper by Prof. Marvin L. Darsie of the University of California, contributed to School and Society of February 2, deals judiciously with this theme-one that is in the forefront of current educational topics of discussion in the United States. The recent development in Germany of authoritarianism in educational as in other fields has proved a powerful irritant provoking such discussion. Prof. Darsie's paper attempts an analysis of some of the complex factors associated with capitalism, scientific technology and the increasing solidarity of organised labour, in which the age-long conflict between the advocates of free intellectual inquiry and the guardians of established doctrine is to-day entangled. Starting from the position that the concepts of freedom and indoctrination have to do with the interweaving of the "two innately conditioned desires for self-expression or pre-eminence and security within the immensely complex maze of social patterns constituting a culture or civilization" he proceeds to consider the resulting problems confronting the educator. The public school teacher functions in an agency maintained by society for the direct purpose of indoctrinating the young with the established institutional patterns: but these represent nuclei of public opinion substantial at the core but with continuously fluctuating margins. It is peculiarly the function of the enlightened teacher "to keep alive this fringe of experimental thinking and at the same time to prevent its detachment from the institutional matrices which guard the stability of any organized society". In this delicate task he must beware of endorsing or promoting any propagandist movement, but his obligation to human welfare requires him to defend and preserve the fringe of free experimental inquiry. The dilemma is discussed in terms of national policies in a short article, "The Great Rift in Education", by Dr. J. F. Abel in School Life of December.

\section{Science News a Century Ago}

\section{Loads Carried by South American Miners}

On April 27, 1835, Darwin set out from Valparaiso on horseback for Coquimbo, which he reached on May 14. On May 12 he stayed at some mines, and writing of the loads carried by the miners, he said : "Captain Hoad has described the wonderful load which the 'Apires', truly beasts of burden, carry up from the deepest mines. I confess I thought the account exaggerated; so that I was glad to take an opportunity of weighing one of the loads, which I picked out by hazard. It required considerable exertion on my part, when standing directly over it, to lift it from the ground. The load was considered under weight when found to be 197 pounds. The apire had carried this up eighty perpendicular yards, - part of the way by a steep passage, but the greater part up notched poles, placed in a zigzag line up the shaft. According to the general regulation, the apire is not allowed to halt for breath except the mine is six hundred feet deep. . . . These men, excepting from accidents, are healthy and appear cheerful. Their bodies are not very musculous. They rarely eat meat once a week, and never oftener, and then only the hard dry charqui. Although with a knowledge that the labour was voluntary, it was nevertheless quite revolting to see the state in which they reached the mouth of the mine; their bodies bent forward, leaning with their arms on the steps, their legs bowed, their muscles quivering, the perspiration streaming from their faces over their breasts, their nostrils distended, the corners of their mouth forcibly drawn back, and the expulsion of their breath most laborious. . . . After staggering to the pile of ore, they emptied the 'carpacho', in two or three seconds recovering their breath, they wiped the sweat from their brows and apparently quite fresh descended the mine again at a quick pace. ..."

\section{Bird Distribution}

Much new light on the distribution of bird life outside Europe was shed at the meeting of the Zoological Society of London on May 12, 1835, with Mr. N. A. Vigors in the chair. The skin of a kiwi, Apteryx Australis, Shaw, sent by the Colonial Secretary for New South Wales, was exhibited, along with an account of the habits of the bird, its probing of the ground with its long bill for earthworms and its scant distribution in New Zealand, whence it had been obtained by a correspondent who had seen only two during his stay there. Colonel Sykes exhibited a series of bird skins presented to the Society from the Cape region of South Africa by Capt. Spiller, and these, stated Sykes, had enabled him to make a comparison with the collection of birds he had shot in India, and those of Europe, to draw up a list of fifteen species of bird found equally in South Africa and India, four species found in South Africa, India and Furope, and two species 'universal', providing Strix Javanica, Horsf. was identical with Strix flammea, Linn. A female hybrid pheasant, Phasianus colchicus, produced by a cock pheasant and greyhen (Tetrao tetrix) from the Merrington Covers of Mr. R. A. Slaney, near Shrewsbury, was exhibited and described by Thomas C. Eyton.

\section{Geology of Seeland and Möen}

At a meeting of the Geological Society on May 13, 1835, Lyell read a paper entitled "On the Cretaceous 